\title{
Friends: Gilbert Romme and the Stroganovs
}

\author{
Victoria Frede \\ University of California, Berkeley \\ vfrede@berkeley.edu
}

\begin{abstract}
:
This article analyzes the intersection of sentimental codes of friendship and pedagogical theory in Russia and France in the second half of the eighteenth century, concentrating on a single group, Aleksandr Stroganov, Pavel Stroganov, and Gilbert Romme. Reading their correspondence in tandem with treatises on friendship and education, the article investigates how such key concepts as equality and virtue were understood at their time. It further explores how they negotiated differences in status and age in constructing what they called a friendship.
\end{abstract}

Keywords:

Enlightenment; sentimentalism; friendship; clientage; childhood education; foreign tutors; Gilbert Romme; Count A. S. Stroganov; Count P. A. Stroganov; Jean-Jacques Rousseau

Friendship does not admit of servitude. Gilbert Romme, a man of letters and adept of Jean-Jacques Rousseau, knew this well. All the same, when in 1779 he entered the employ of the Russian magnate, Aleksandr Stroganov, Romme insisted on being hired as a friend to the family. His employer fully complied. Their decision to construct their relationship as a friendship, I will argue, was fully conscious and indeed accorded with the ethical norms that entered circulation in France and Russia under the aegis of the Enlightenment.

The Enlightenment involved a reimagining of interpersonal relationships, shifting attention away from service and obligation, and placing new value on the individual's voluntary dedication of merits and faculties. Friendship played a central role in this realignment of priorities, as seen in Émile (1762), where Rousseau identified friends as the opposite of protégés:

"The only tie of my associations would be mutual attachment, conformity of tastes, suitability of characters. [...] I would never permit their charm to be poisoned by interest. [...] I would want to be surrounded by a society, not a court; friends, and not protégés. I would not be the patron of my guests, I would be their host. Independence and equality would grant my relationships all the candor of benevolence; and where neither duty nor interest entered in any way, pleasure and friendship would alone make the law."

Rousseau's thoughts in this passage are built a round a series of binaries: friendship is identified with mutual attachment, likeness of character and taste, independence,

${ }^{1}$ Jean-Jacques Rousseau, Émile, ou De l'éducation (Paris: Gallimard, 1969), 519. All translations are mine. 
equality, candor, benevolence, and pleasure, all set in contrast against patronage, courtliness, obligation, and interest. Pointing to this passage in Émile, Allan Silver credited Rousseau for having "strikingly proclaim[ed] the coming of the modern friendship ideal." ${ }^{2}$ Silver, like other scholars, situated the rise of the sentimental cult of friendship amid the waning of the ancien régime in Britain and western Europe, marked by new social, economic, and political structures. ${ }^{3}$ As Silver warned, however, the ideal did not become reality overnight. The term "friend" continued in the eighteenth century to be applied to a wide array of persons to whom one felt attached, including patrons and clients, as well as close relatives. ${ }^{4}$

In Russia, unlike in Western Europe, the ancient regime showed few signs of waning. Though patron-client relations continued to organize political life, however, certain forms of dominance, dependence, and servility did come to seem unpalatable and degrading, and interpersonal relationships needed in certain cases to be recast, to be reinvented as voluntary, independently felt commitments, predicated on candor, attachment, and selfless devotion. Friendship as an institution and as an ideal proved valuable in this context. These tendencies were clearly displayed in the association between Gilbert Romme, Aleksandr Stroganov, and Pavel Stroganov from 1779 to 1790. Seventeen years after the publication of Émile, father and tutor set out to recreate in Russia the educational principles outlined by Rousseau. ${ }^{5}$ Rousseau made friendship the essential component in the association between them, positing that candor, trust, and lack of compulsion were essential for the successful upbringing of a child. ${ }^{6}$.

\footnotetext{
${ }^{2}$ Allan Silver, "Two Different Sorts of Commerce': Friendship and Strangership in Civil Society," in Jeff Weintraub and Krishan Kumar, Public and Private in Thought and Practice (Chicago: University of Chicago, 1997), 65-66.

${ }^{3}$ Klaus Lankheit, Das Freundschaftsbild der Romantik (Heidelberg: Carl Winter, 1952); Wolfdietrich Rasch, Freundschaftskult und Freundschaftsdichtung im deutschen Schrifttum des 18. Jahrhunderts (Halle: Max Niemeyer, 1936); Anne Vincent-Buffault, L'exercice d l'amitié: Pour une histoire des pratiques amicales aux XVIIIe et XIXe siècles (Paris: Seuil, 1995).

${ }^{4}$ Silver, "Two Different Sorts of Commerce'," 58-59. Sixteenth and seventeenth century meanings of "friend" and "friendship" are discussed in Sharon Kettering, "Friendship and Clientage in Early Modern France," French History 6, 2 (1992): 139-58.

${ }^{5}$ The relationship between the Stroganovs and Romme has been written about extensively, largely due to Romme's later participation in the French Revolution. Pavel Stroganov's education and the influence of Rousseau on Romme have also been described at length. The original contribution of my article consists in analyzing the reasons for and consequences of their use of the sentimental language of friendship. The most notable works are: Alessandro Galante Garrone, Gilbert Romme: Histoire d'un révolutionnaire, 17501795(Paris: Flammarion, 1971); Aleksandr Chudinov, Zhil'ber Romm i Pavel Stroganov: Istoriia neobychnogo soiuza (Moscow: NLO, 2010); Marc de Vissac, Romme le Montagnard: Un conventionnel du Puy-de-Dôme (Riom: Leboyer, 1883); P. I. Bartenev, "Zhil'ber Romm. K istorii Russkoi obrazovannosti novogo vremeni," Russkii arkhiv no. 1 (1887): 5-38; V. M. Dalin, "Zhil'ber Romm, Pavel Stroganov i Sankt-Peterburgskii dvor," Voprosy istorii no. 6 (1966): 207-13; Dominique Julia, "Gilbert Romme, gouverneur (1779-1790)," in Gilbert Romme (1750-1795): Actes du colloque de Riom, ed. Jean Ehrard (Paris: Société des Études Robespierristes, 1995), 43-78.

${ }^{6}$ Rousseau, Émile, 99, 255.
} 
The purpose of this article is to analyze why friendship seemed necessary and compelling to Romme and the Stroganovs, and what problems, practical and theoretical, stood in their way. The analysis will require some consideration of how they and their contemporaries interpreted the concept of friendship, as well as virtue, equality, and independence, and how these concepts organized their behavior and decisions. All these concepts underwent modification in the course of the eighteenth century, and these modifications brought with them new norms of comportment. The Encyclopédie's entry on "natural equality," for example, instructed its readers to "esteem and treat their inferiors just as beings who are their equals by nature." 7 The kind of friendship that developed between Romme and the Stroganovs should be understood in the light of this "just as." Independence and candor were highly valued attributes among members of the political and intellectual elites in the late eighteenth century. Friendship encouraged, indeed trained individuals to behave according to these ideals.

\section{Narrative overview}

Count Aleksandr Sergeevich Stroganov was one of the richest men in Russia in 1779, when he hired Gilbert Romme as tutor to his seven-year-old son, Pavel. A courtier, Stroganov had served Catherine II for several years in the 1760s, though he did not succeed in gaining her favor. ${ }^{8}$ In the early 1770s, Stroganov left St. Petersburg with his second wife, Ekaterina Petrovna Stroganova (née Trubetskaia) to live in Paris, where they socialized with other itinerant members of the Russian high nobility as well as with members of the French republic of letters. Among their acquaintances was a distant relative of Stroganov's, Count Aleksandr Aleksandrovich Golovkin, an eccentric well known for his interest in philosophy and pedagogy. Fascinated by the views elaborated by Rousseau in Émile, Golovkin had vowed to raise his own children, Georges and Amélie, according to its precepts. He reserved for himself the role of principal educator to his children, but hired a small army of tutors to instruct them in specific disciplines, including Gilbert Romme, an aspiring medic with a strong interest in mathematics and physics. Romme, the son of a prefect in Riom, Puy-de-Dôme in the Auvergne, had moved

\footnotetext{
7 Chevalier de Jaucourt, "Egalité naturelle (droit naturel)," Encyclopédie ou Dictionnaire raisonné des sciences, des arts et des métiers. Vol. 5 (Paris: Briasson et al., 1755), 415.

${ }^{8}$ Galante Garrone, Gilbert Romme, 103n1. Stroganov's failure must have been all the more galling, since he had supported Catherine II's assent to power. According to Dashkova, Catherine II regularly referred to the count as "le magot" (the Barbary-ape), due to his awkward physique and ribald sense of humor. E. R. Dashkova, "Mémoires" in Arkhiv kniazia Vorontsova. Vol. 21. Bumagi E. R. Dashkovoi (Moscow: Universitetskaia tipografiia, 1881), 56-57. Stroganov's success with Catherine and at court may further have been hampered by his bad gambling habit, as well as by sordid rumors and jokes about his marital life that circulated, extending to the diplomatic corps. See S. O. Kuznetsov, Pust' Frantsiia pouchit nas 'tantsovat" (St. Petersburg: Nestor, 2003), 335-7. See also Mikhail Longinov, "Satiricheskii katalog pri dvore Ekateriny II-i," Russkii arkhiv 9 (1871), stolb 2039-54: 2041, 2042, 2047n10; Henry Shirley to Lord Weymouth, 28 February (1o March) 1768. In Sbornik russkogo istoricheskogo obshchestva 12 (1873): 328-29; diary entry for 30 March 1776 in Chevalier de Corberon, Un diplomate Français à la cour de Catherine II, 1775-178o, 2 vols. (Paris: Plon, 1901), 1: 194; A. D. Bludova, "Vospominaniia," Russkii arkhiv 27: 1 (1889): 39-106, here 77.
}

(cc) EY LUKE UNIVERSTYY 
to Paris in 1774 to pursue his studies, but worked as a tutor to support himself. Strong bonds tied him to home, especially to his friends Gabriel Dubreul, son of Riom's postal director, and Jacques Démichel, son of a candy maker. Their intensive correspondence will furnish key documents for this study. Romme's gift for friendship appears to have made a strong impression on Aleksandr Golovkin, who made him a frequent guest in his home.

When Aleksandr Stroganov decided to return to Russia to resume his career at court in 1779, Golovkin arranged for Romme to enter the Stroganovs' employ. Romme hesitated, despite the rich rewards offered to him for his services. ${ }^{9}$ As he explained to Dubreul a few months after signing the contract, he had not wished to become any person's employee, "chained [...] by gold," but reconciled himself to serving the Stroganovs as "a friend of the household," a status he hoped would allow him to preserve a relationship of "liberty, sincerity, friendship, and trust" with them. ${ }^{10}$ In short, Romme hoped to reproduce in St. Petersburg the kind of relationship he had cultivated with the Golovkins in Paris. Romme's relationship with Aleksandr Stroganov ran smoothly for twelve long years, though the count's life was clouded by scandal in 1781, when Catherine II forced his wife, Ekaterina, to leave St. Petersburg permanently (Catherine discovered that her former favorite, Ivan Nikolaevich Rimskii-Korsakov, was having an affair with the countess). ${ }^{11}$

Lodged in the massive Stroganov palace in St. Petersburg, Romme and Pavel shared a life at close quarters, and relations between the sensitive and gloomy governor and the teen-age boy were far from straightforward. In 1786 Romme persuaded Aleksandr Stroganov to let the pair travel to Geneva and Paris to complete Pavel's education. ${ }^{12}$ They were in Paris when the 1789 revolution broke out and, bedazzled, they observed

\footnotetext{
${ }^{9}$ Romme was to be paid between 2,400 and 3,00o livres per year, a very substantial sum. Anne Mézin and Vladislav Rjéoutski, eds., Les Français en Russie au siècle des Lumières, 2 vols. (Ferney-Voltaire: Centre international d'étude du XVIIIe siècle, 2011), 2:722. Chudinov believes, perhaps rightly, that Romme took this position for want of any better alternative after what he calls a "fiasco" of an attempt to join the French republic of letters. Chudinov also represents Romme's efforts to educate Pavel as dilatory. Evidence includes Romme's letters to Dubreul and Démichel, which, he alleges, rarely discuss Pavel's wellbeing. Chudinov, Zhil'ber Romm, 129, 157, 170-1. I have read the same materials but come to different conclusions. Romme certainly needed money and employment. Yet, he viewed mercenary motivations as degrading. Joining the Stroganovs as a "friend of the household" rather than a man for hire allowed him to save face in a position that would otherwise have appeared to him as servile.

${ }^{10}$ Gilbert Romme to Gabriel Dubreul, [8 August 1779], Correspondance, 2 vols. ed. Anne-Marie Bourdin et al. (Clermont-Ferrand: Presses Universitaires Blaise-Pascal), 2: 577.

${ }^{11}$ The affair began almost as soon as the Stroganovs returned from France, in 178o. Chudinov, Zhil'ber Romm, 156-57.

${ }^{12}$ Romme to Aleksandr Stroganov, March 1786, in Graf Pavel Aleksandrovich Stroganov [hereafter: GPAS], ed. Grand Duke Nikolai Mikhailovich, 3 vols. (St. Petersburg: Ekspeditsiia zagotovleniia gosudarstvennykh bumag, 1903), 1: 267. "You know very well yourself that his education cannot be achieved in Russia [....] He shall turn fourteen in a few months; if he is not introduced to serious and dedicated studies at that age [...] his education will have failed entirely."
} 
developments at increasingly close range, attending sessions of the National Assembly, joining the Societé des Amis de la Loi, and-very briefly for Pavel-the Jacobin Club. ${ }^{13}$ Aleksandr Stroganov's increasingly insistent pleas that they leave France went unheeded. ${ }^{14}$ Indeed, Romme claimed to be offended by them. "For the first time since I have had the honor of representing you before your son, you have made me feel the enormous distance which there is between a father and a tutor," as he wrote from Paris in July 1790. ${ }^{15}$ Catherine II had already ordered all Russians to leave Paris, but she now explicitly demanded that the count fire Romme, which he did in September $179{ }^{16}$ Unofficially, Romme was warned that Catherine would banish him to the frontiers of the empire if ever he tried to return to Russia. ${ }^{17}$ In late December, a small expedition arrived to collect Pavel, aged 18, but not before he and Romme had vowed eternal friendship before the tomb of Rousseau. Departing, Pavel carried with him two treasured gifts: a bust of Rousseau, and a manuscript of notes Romme had once taken on Émile. ${ }^{18}$

Romme claimed to have been taken aback by the "enormous distance" that Stroganov had suddenly made him feel in the summer of 1790. Given the circumstances, however, their performance of friendship for so many years, adhering to the rhetorical and behavioral rules of the sentimental cult, was a remarkable accomplishment.

\section{The governor as friend: Rousseau, Romme, and the Golovkins}

Rousseau's Émile stipulated that a governor must be a friend to both father and son. A parent must never hire a man to care for his children: a paid governor is nothing more than a "man for sale," and the pupil of such a servant could only become a servile adult. "Fais-toi donc un ami," the father is told. ${ }^{19}$ Just as the governor was to be a friend to the father, so he was also to be "the friend, the comrade, the companion" to the boy. Only the assistance of a friend could make a man of the boy, who must learn to form the right judgments independently. He must behave correctly because his mind has formed the right dispositions, not in order to earn praise and avoid condemnation of others. ${ }^{20}$ An

\footnotetext{
${ }^{13}$ Chudinov, Zhil'ber Romm, 252-3, 261-75; Galante Garrone, Gilbert Romme, ch. 5.

${ }^{14}$ Aleksandr Stroganov to Romme, 12 March 1790, GPAS, 1: 251: "Well now, beautiful weather will soon arrive, and I suppose that you shall benefit by making a few journeys." His next letter was more urgent in tone: Aleksandr Stroganov to Romme, 20 June 1790, GPAS, 1: 251-2. See also Galante Garrone, Gilbert Romme, 237-38.

${ }^{15}$ Romme to Aleksandr Stroganov, 22 July 1790, GPAS, 1: 275. Dated according to Galante Garrone, Gilbert Romme, 238n2.

${ }^{16}$ Chudinov, Zhil'ber Romm, 288-95; Dalin, “Zhil'ber Romm, Pavel Stroganov i Sankt-Peterburgskii dvor," 208-10; Aleksandr Stroganov to Romme, 21 September 1790, GPAS, 1: 252-53.

${ }^{17}$ Démichel to Romme, 27 October 1790; 11 November 1790, Bibliothèque nationale de France. Département des manuscrits [hereafter: BNF] 4790, Microfilm 8640, 156 and verso, 157.

${ }^{18}$ Galante Garrone, Gilbert Romme, 238-39; Julia, "Gilbert Romme, gouverneur," 78n161. Pavel Stroganov to Romme, 14 December 1790, GPAS, 1: 308. The bust was by Houdon, who like Romme and Stroganov, had belonged to the Nine Sisters Lodge in Paris.

${ }^{19}$ Rousseau, Émile, 99.

${ }^{20}$ Rousseau, Émile, 255-9; 281, 385-7.
} 
imaginary tutor, Jean-Jacques, showed how it could be achieved with an imaginary boy, Émile. The father and mother remain unnamed.

Friendship played a distinctive role in Émile, yet Rousseau had not invented the idea of the governor as friend. He may have borrowed it from François de Salignac de la Mothe-Fénelon's Les Aventures de Télémaque (1699), a book Rousseau is known to have admired. ${ }^{21}$ Here, friendship was repeatedly invoked as uniting Telemachus and his guide, Mentor, as well as Mentor and Telemachus' father, Ulysses. Telemachus, in search of his missing father, loves, trusts, and confides in Mentor, turning to him for moral counsel as well as for consolation..$^{22}$ Widely read in its day, this work strongly influenced popular pedagogical writings of the mid-eighteenth century, such as Caraccioli's Le Véritable Mentor (1756), where the governor was instructed to present himself as his pupil's closest friend. Likewise, the Encyclopédie's entry, "Gouverneur d'un jeune homme" (1757), emphasized that the tutor must win the pupil's "trust" and "friendship" so as to "shape his heart with respect to moral virtues." ${ }^{23}$

The influence of these early tracts in the mid-eighteenth century can be detected in the upbringing of Aleksandr Stroganov himself. His own father, Sergei Grigorievich Stroganov had not neglected his education. Fénelon's Télémaque, at that time the most widely read French book in Russia, seems to have played a formative role. ${ }^{24}$ Appreciating the growing value placed on French language and culture at court in St. Petersburg, Sergei had placed Aleksandr in the hands of Jean Antoine, a French-speaking tutor, albeit one of Prussian extraction, in the late 1740s. Both father and son became strongly attached to "Gospodin Antonii," as they referred to him in their letters, and he remained

\footnotetext{
${ }^{21}$ Rousseau's debt to contemporary educational theorists is described in Marcel Grandière, L'Idéal pédagogique en France au dix-huitième siècle (Oxford: Voltaire Foundation, 1998), 129-46. On Rousseau and Fénelon, see Judith N. Shklar, "Roussseau's Two Models: Sparta in the Age of Gold," Political Science Quarterly 81, 1 (1966): 28-29. References to Jean-Jacques and Émile as Mentor and Telemachus can be found in Émile, 611, 625, 685 .

${ }^{22}$ François de Salignac de la Mothe Fénelon, Les Aventures de Télémaque, fils d'Ulysse, 2 vols. (Paris: Delauline, 1730), 1: 3, 86, 145, 2: 232. While a line can be traced between Fénelon and Rousseau, and both show that the pupil's affection for his educator enhances the educator's influence over him, there were many important differences between them. Fénelon's Mentor helps Telemachus cultivate his good dispositions by serving as his guide, offering comfort and advice, often in long monologues, though he disappears from time to time, allowing Telemachus to form his own experiences. Rousseau's Jean-Jacques is ever-present, guiding Émile by organizing his day-to-day activities and helping him to reflect on them, while keeping instructions to a minimum. Émile's dispositions are the products of these minutely arranged experiences.

${ }^{23}$ Louis-Antoine Caraccioli, Le Véritable Mentor, ou l'éducation de la noblesse, $4^{\text {th }}$ ed. (Liège: Bassompierre, 1765), 81, 131; Lefebvre, "Gouverneur d'un jeune homme," Encyclopédie ou Dictionnaire raisonné des sciences, des arts et des métiers Vol. 7 (Paris: Briasson et al., 1757), 792-98: 792, 794.

${ }^{24}$ The Stroganovs are known to have owned at least one copy of Fénelon's book: V. A. Somov, "Kabinet dlia chteniia grafa Stroganova," in Vek prosveshcheniia; Le Siècle des lumières. Vol. 1. Prostranstvo evropeiskoi kul'tury v epokhu Ekateriny II, ed. S. Ia. Karp (Moscow: Nauka, 2006), 232-69: 241.
} 
with the family for many years. ${ }^{25}$ In 1752, when Aleksandr and Antoine departed for Europe on a five-year Grand Tour, Sergei Stroganov commissioned a special painting to adorn the central hall of his palace on Nevskii Prospect: Telemachus and Mentor set off on their travels together, with Mercury, patron of travelers, hovering over their heads. ${ }^{26}$ The commission not only demonstrates the importance Sergei attached to his son's educational tour, but also his ambitions for his son as a future statesman. In Télémaque, Mentor's advice extends to the manner in which Telemachus should govern Ithaca if ever he succeeds Ulysses as king. By commissioning a representation of Telemachus and Mentor for his palace, Sergei Stroganov advertised his family as a dynasty of wise rulers; Aleksander Stroganov would return from his travels as a prudent and judicious prince, ready to become a leader of men. ${ }^{27}$

During his travels with Antoine, Aleksandr Stroganov displayed due deference to the guiding text of his voyage, as shown in a treatise he wrote while in Geneva in 1753, "Letter to a Friend on the Manner to Travel Usefully." A young man leaving home for the first time needed "a faithful friend, just as Telemachus had a Mentor," for he was all too susceptible to the corrupting influence of an alien environment and his own bad inclinations. A "governor" was the remedy, the "greatest good" (le plus grand bonheur) for the young man, especially if he was "extremely attached to his pupil." This remark was followed by a quotation from Seneca about the benefits of friendship: "Nothing is as sweet to the soul as a tender, loyal friendship. What a benefit it is to have found friends in whose bosom you can deposit all of your secrets, whose conversation softens your cares, whose gaiety dissipates your sorrows, whose prudence gives you good counsel, and the very sight of whom causes you to rejoice." ${ }^{28}$

Educational treatises gained wide currency in the eighteenth century and were read and discussed assiduously, but few noblemen studied them as diligently as Aleksandr Golovkin. Rousseau's Émile, the boldest new educational tract, became his dominant inspiration in raising his children. So carefully did Golovkin apply its lessons that his son, Georges, became known to contemporaries-including Rousseau himselfas the "living Émile." ${ }^{29}$ Romme admired Golovkin's dedication to Rousseau's principles, noting with approval the thoroughness with which Golovkin oversaw its application. "He

\footnotetext{
${ }^{25}$ Kuznetsov, Pust' Frantsiia pouchit nas 'tantsovat', 145-46. Aleksandr and Sergei Stroganov repeatedly referred to Antoine in their correspondence between 1752 and 1756 . See the volume published as an appendix to Kuznetsov, Pust' Frantsiia pouchit nas 'tantsovat" [hereafter: Prilozheniia], 366-467: 368, 373-4, 429, 448. Jean Antoine remained a fixture in the Stroganov household as late as 1769 , welcoming guests when count Aleksandr Stroganov was not present. Somov, "Kabinet dlia chteniia grafa Stroganova," 236.

${ }^{26}$ On Télémaque as a source for the plafond and art-historians' debates about it, see Kuznetsov, Pust' Frantsiia pouchit nas 'tantsovat", 188-96. I inferred that Sergei Stroganov commissioned this segment of the plafond to commemorate the departure of Aleksandr Stroganov and Monsieur Antoine, based only on the fact that it was painted around the time that they left.

${ }^{27}$ The scene on the plafond is described as the allegory of "good governance" and of a future golden age in Kuznetsov, Pust' Frantsiia, 189, 196.

${ }^{28}$ Aleksandr Stroganov, "Lettre à un Ami sur la manière de Voyager utilement," in Kuznetsov, Prilozheniia, 478; Kuznetsov, Pust' Frantsiia, 161-62.

${ }^{29}$ Julia, "Gilbert Romme, gouverneur," 50.
}

(cc) EY DU DUE UNIVERSTYY 
has taken upon himself the task of shaping the[ir] heart," he explained joyfully in a letter to Dubreul. Golovkin cultivated an atmosphere of simplicity, tenderness, and intimacy in his home, and the children, Romme claimed, were full of love for their father. Importantly, they were also capable of independent action, and above all, devoid of "the fatuousness, amour-propre, and self-importance" so common among people of high birth. They avoided high society, but gathered with friends in their home. ${ }^{30}$

Romme was apparently counted among their friends. Describing these relations to Dubreul in 1775, he initially expressed suspicion that there might be something artificial in Golovkin's kindnesses, speculating that his employer might merely cultivate personable manners with tutors for the benefit of his children:

"This gentleman has too much education and is too well raised not to feel that the character traits of honesty, affability, and a certain familiarity are absolutely necessary in order to gain the firm allegiance of persons whom one summons on behalf of one's son, as well as to diminish, so to speak, the venality of their souls in raising them $[$ sic]. I should hesitate to think that these are truly the sentiments that lead Mr. Golovkin to give me his friendship. The esteem I have developed for him is contrary to this idea; and I myself would be too humiliated. Yet I think if a mode of conduct can be interpreted in two ways, then this should be sufficient [reason] to make one doubt both interpretations and [refrain from] affirming one over the other." ${ }^{31}$

Over time, however, Romme grew more confident, expressing pride in their close friendship: "I am attached to him for life." ${ }^{2}$ Romme and Golovkin would maintain an intensive correspondence after Romme's departure from France in 1779 until Golovkin's death in 1781. Georges and Amélie, too, remained in contact with Romme. ${ }^{33}$ Their ability to live up to, or enact, the principles Rousseau had outlined can be seen in Georges' farewell letter to Romme in 1779: "We are men, thanks to God, and we are friends, attached for ever. [...] Your faithful disciple will [...] one day hold you in his arms, a brave and honest and useful man. What joy! What bliss!"34

Negotiations between Romme and Aleksandr Stroganov as to his future employment took place in this highly protective setting, and Aleksandr Golovkin played a key role in persuading Romme to enter Stroganov's service. So, too, did Countess Marie Henriette Augustine Renée d'Harville, whom Romme met through Golovkin, and who

\footnotetext{
${ }^{30}$ Romme to Dubreul, [summer 1778], Correspondance, 2: 432.

${ }^{31}$ Romme to Dubreul, 22 April [1775], Correspondance, 1: 195.

${ }^{32}$ Romme to Dubreul, [summer 1778], Correspondance, 2: 431.

33 Romme to Dubreul, Museo del Risorgimento di Milano, 2649 [hereafter: MRM], carton 14, letter 3, 5 November 1782; carton 14, letter 4, 26/6 August 1782; carton 17, letter 6, [November 1786]. Folios in this archive are unnumbered.

${ }^{34}$ Georges Golovkin to Romme, 27 June 1779, Correspondance, 2: 568.
} 
shared their pedagogical interests. ${ }^{35}$ She became as close to Romme as Golovkin, inviting him to stay in her home and offering him counsel. When he finally agreed to take charge of Pavel Stroganov's education, Romme appears partly to have been motivated by loyalty to them and by the wish to honor their commitment to educational principles. ${ }^{36}$

There is one other reason why Romme's friendship with Golovkin and d'Harville mattered: he had grown accustomed to the society of people of higher rank well before he was hired by Count Stroganov. Golovkin and d'Harville too, held the title of count, even if they were less wealthy and powerful than Stroganov. This fact is important, since the social inequality that set Romme apart from Stroganov might appear to have militated against the formation of a friendship between them. How important was such inequality, in theory?

\section{Equality. Social difference and personal worth}

Eighteenth-century treatises on friendship presented long lists of preconditions necessary for the development of true friendship, including virtue, compatibility of character, shared tastes and dispositions, as well as mutual attraction. Louis Silvèstre de Sacy defined it this way in his famous treatise of 1703: "Friendship is nothing other than a perfect union of hearts, formed by merit and by virtue, and confirmed by the resemblance of morals." ${ }^{37}$ Equality, too, was frequently listed as a necessary prerequisite, but what exactly it meant and how to measure it remained unclear. A key term in geometry, equality was understood as a "relation between two or more things that have the same size, the same quantity, or the same quality." ${ }^{8}$ Between people, it could refer to likeness of personal attributes, and therefore to compatibility, though it could also refer to personal worth. Calculating a person's worth required factoring in several attributes, including social rank and wealth, but also virtue, reputation, education, erudition, and personal connections.

Importantly, friendship tracts of the eighteenth century did not demand that friends belong to the same social rank. Most of these treatises agreed that "merit" mattered more than rank, while virtue mattered most of all. Admittedly, some

\footnotetext{
${ }^{35}$ Galante Garrone, Gilbert Romme, 87. See also Romme to Dubreul, 11 May 1779, Correspondance, 2: 530.

36 "It is the friendship of the good Count Golovkin which formed an engagement that I tremble to fulfill." Romme to Dubreul, MRM, carton 14, letter 2, 6-8 June 1782. See also Romme to Aleksandr Stroganov, [1786], GPAS, 1: 258, 259.

${ }^{37}$ Louis Silvèstre de Sacy, Traité de l'amitié, Nouvelle édition (Paris: Compagnie des Libraires, 1722), 4-5. Louis Antoine de Caraccioli, Les caractères de l'amitié, Nouvelle édition (Frankfurt, Liege, and Brussels: Bassompiere et al., 1761), 139. "True friendship" is defined as "a community of sentiments and of will, of joy and of affections; the union of several hearts, which inclination gives birth to, which the resemblance of morals favors, which merit upholds, and which virtue renders eternal." [Jean-Baptiste Aubry], L'ami philosophe et politique (Paris: Barrois, 1776), 4, 20.

38 "Égal," Encyclopédie, 5:413. The Encyclopédie’s entries "Égal" and "Égalité" began with mathematics, logic, and astronomy, only then moving to definitions that pertained to human beings. In referring to people, for example, it could mean an even temper. The very last entry (5:415) was the most famous, "Egalité naturelle," defined as "that which exists between all people by virtue of the constitution of their nature alone."
}

(c)) EY DU U UNAVERSTY 
combinations seemed unlikely to prove fruitful, regardless of personal qualities, such as between a master and his valet, a "princess and a shepherdess," or between sixty-year-old and a twenty-five-year-old. ${ }^{39}$ In addition, they noted that kings, princes, and magnates were unlikely to find friends, though they might desire them: courts were treacherous places, marked by insincerity, attracting ambitious and unscrupulous individuals. August personages also lacked the time and patience to cultivate friendships. Their subjects, even the worthiest, were likely to be constrained by fear. Yet, as authors of friendship treatises conceded, even sovereigns could make and keep friends if they chose carefully and helped their friends "forget" differences in station. ${ }^{40}$ This was an age that wanted to believe in friendship, as well as in equality, a mandate of rationality and moral virtue.

The secondary importance attached by authors of friendship tracts to social equality is further demonstrated in passages in which authors pointed out that equality of rank, too, could impose burdens, such as the competition naturally occurring between people of the same profession. ${ }^{41}$ Indeed, as Caraccioli's Les caractères de l'amitié (1760) argued, there were cases in which inequality of station might prove fruitful, such as between people of high birth and men of letters. Talent, wit, and reputation weighed in the latter's favor, and instead of competing, the two complemented one another: "Since talents are ordinarily more widespread among men who are obliged to live by their wits and hard work, they provide a good supplement to the nobility which [such people] lack." ${ }^{42}$ Last, but not least, many treatises asserted that friends became equals as a result of their shared experiences and the exchange of confidences. Friendship, with its bonds of intimacy, had the power to "create" equality. ${ }^{43}$

Golovkin, d'Harville, and Romme appear to have complemented one another in the ways that Caraccioli described, and Romme's relationship to Aleksandr Stroganov, too, fit this description. Stroganov enjoyed the company of learned men, and he did his best to make others feel comfortable. His simple manner made a favorable impression on Romme, as he reported to Démichel, who relayed it to Dubreul in 1778: "Romme

\footnotetext{
${ }^{39}$ Caraccioli, Les caractères de l'amitié, 16-17, 152. The difficulties imposed by differentials in age and power were most strongly emphasized by Marie Geneviève Charlotte Thiroux d'Arconville, De l'amitié, $2^{\text {nd }}$ ed. (Amsterdam: Desaint \& Saillant, 1764), 23, 102.

$4^{\circ}$ Sacy, Traité l'amitié, 241, 246-7, 254-7; Caraccioli, Les caractères de l'amitié, 124-5, 142; Thiroux d'Arconville, De l'Amitié, 97-105. A particularly pessimistic account of princes is Charles de Saint-Evremond, "Sur l'amitié à Madame la Duchesse Mazarin," in Les oeuvres de M. de Saint-Evremond, publiés des manuscrits $5^{\text {th }}$ ed. (Amsterdam: Covens and Mortier, 1739), 3: 409-11.

${ }^{41}$ Sacy, Traité l'amitié, 55-56. Even Thiroux d'Arconville agreed that competition could undermine friendship between people of equal station, particularly professional men of letters. Thiroux d'Arconville, De l'amitié, 129-34.

${ }^{42}$ Caraccioli, Les caractères de l'amitié, 18.

43 [Laurent] Bordelon, Les caractères de l'amitié (Paris: Le Febvre, 1702), 35-6. Caraccioli, Les caractères de l'amitié, 15-16. Sacy, Traité l'amitié, 57. See also Abbé Bruté de Loirelle, L'héroisme de l'amitié: David et Jonathas: Poème en quatre chants (Paris: Frères Estiennes, 1776), 6-7. This poem recounts how a "shepherd" and a prince, David and Jonathan, became equals through "brotherly love" (amitié fraternelle).
} 
portrayed him to me as a very amiable lord (seigneur) who puts people at their ease." Admittedly, the extent of Stroganov's wealth and status appears to have been difficult to set aside, as highlighted in Démichel's next sentence: "He is decorated with a blue sash (cordon bleu), he enjoyed 400 thousand livres in income when he arrived in Paris and is now reduced to under 200." Stroganov's wealth must have been a frequent subject of conversation, making it difficult to "forget." Yet, Démichel went on to describe how important arts and letters were to Stroganov, who invited well-known writers and artists ("les plus célèbres") to his home twice a week. ${ }^{44}$ Stroganov's eagerness for contact with erudite people may therefore have made Romme attractive to him. The latter was not a celebrated writer, but he was well educated - better educated, at least, than Stroganov.

People whom Stroganov respected held Romme in high esteem. Stroganov was a freemason, initiated in Paris in 1773, and later became a member at large of the prestigious "Nine Sisters" lodge, to which several of France's most illustrious writers and philosophes belonged. Romme was not only a member of that lodge, but was promoted in 1778 to the rank of "expert," a title that qualified him to play an important role in the lodge's rituals. ${ }^{45}$ The lodge's members took pride in masonry's ability to unite men whom "nature, climate, language, circumstance, interest, forms of government, and mores" had divided. ${ }^{46}$ Every lodge placed its members on a level with one another; in the Nine Sisters, they referred to one another as "brother and friend," and they were supposed to approach one another as role models ("émules"). ${ }^{47}$

Shared experiences in the lodge would indeed have helped to create equality between Stroganov and Romme. These prior experiences, together with shared commitments to education, formed a solid basis for Stroganov and Romme to name one another friends.

\section{Romme and Aleksandr Stroganov as friends}

Treatises on education emphasized that parents should choose governors with care, and vice versa. The Stroganovs and Romme proceeded accordingly. The Stroganovs had hired and fired several instructors before they offered an appointment to Romme, whom they had known since 1775 or 1776 . What little is known about their early interactions was recorded by Romme's friends Dubreul and Démichel. According to their letters, Aleksandr Stroganov and Romme developed a warm rapport relatively quickly, while relations between Ekaterina and Romme remained frigid (Romme had apparently

\footnotetext{
${ }^{44}$ As reported in a letter by Dubreul to Démichel, 23 May 1778, quoted in Correspondance, 2: 472 n. 5 .

${ }^{45}$ Alexandre Stroev, "Gilbert Romme et la loge de Neuf Soeurs (juillet 1779)," in Les Archives de l'Est et la France des Lumières: Guide des fonds inédits 2 vols. (Ferney-Voltaire: Centre international d'étude du XVIIIe siècle, 2007), 2: 673-6; Louis Amiable, Une loge maçonnique d'avant 1789, la R. L. les Neuf Soeurs (Paris: Alcan, 1897), 390, 393.

${ }^{46}$ Extract from a speech by Jérôme la Lande during Voltaire's initiation into the lodge, reproduced in German translation in Journal für Freymaurer als Manuskript gedruckt (Vienna: Wappier, 1784), 235-6.

${ }^{47}$ Amiable, Une loge maçonnique d'avant 1789, 45-46.
} 
described her to Démichel as "stern" and "cold"). ${ }^{48}$ These tensions may have given Romme pause, as did anxiety about the prospect of moving to Russia, a place far from home and wholly unknown to him. The prospect certainly evoked anxiety in his friends, who feared that the climate might impact his health aversely, or that Eastern Orthodoxy might corrupt his religious faith. ${ }^{49}$ Last, but not least, Romme took a risk by leaving family and friends, placing himself under the sole guardianship of the Stroganovs. His contract stipulated that he could return to France at any time, and Golovkin and d'Harville reassured him that they would support him in any eventuality. ${ }^{\circ}$ Golovkin took this obligation seriously, as he wrote to Stroganov in 1780: "Never forget that Romme is my friend; do not let anyone forget it." ${ }^{51}$

In the end, Romme appears to have hoped that his good and close relations with Golovkin and his children would transfer themselves to the Stroganovs. Writing to reassure Gabriel Dubreul about his decision, Romme identified in Aleksandr Stroganov the same qualities that drew him to Golovkin. If Golovkin was "true," "frank," "worthy of esteem," ${ }^{2}$ then Stroganov was "frank, simple, affable, known and loved by his compatriots." ${ }^{3}$ Stroganov and Golovkin possessed the "same uprightness (droiture), the same nobility of sentiments, the same love of the good," and Romme even found points of comparison in their biographies. ${ }^{54}$ Once in Russia, Romme continued to report favorably of his relations with Stroganov, describing how impressed he was by the count's attentions, who made every effort to welcome him into his new home. Personally escorting him around his massive palace in St. Petersburg, "the count showed me into my apartment," saying, "this here is your kingdom, my dear friend." 55 Similar reports followed in the next years: Aleksandr Stroganov treated him with ever greater "interest, gentleness, and affability"; with "sincerity and honesty"; in short, "like a friend." "He treats me like a friend, and this title makes us forget all the other connections of duties and engagements, without losing sight of the object." By July 1781, Romme expressed even more confidence, describing the "sincere friendship and trust accorded to me by the good

\footnotetext{
${ }^{48}$ Dubreul to Démichel, 23 May 1778, quoted in Correspondance, 2:472n5. Démichel to Dubreul, 22 May 1779, quoted in Correspondance, 2: 532n1.

${ }^{49}$ Dubreul to Romme, 20 May [1779] and Antoine Boirat to Romme, Correspondance, 2: 540, 544.

${ }^{50}$ The contract, housed in Rossiiskii gosudarstvennyi arkhiv drevnikh aktov [hereafter: RGADA], f. 1278, op. 1, d. 348, ll. 3-4, was most recently reproduced in Chudinov, Zhil'ber Romm, 148. D'Harville repeatedly offered Romme her protection should he wish to leave the service of Stroganov and return to France: Hélène Rol-Tanguy, "Mme d'Harville" in Romme, Correspondance, 2: 678.

${ }^{51}$ Aleksandr Golovkin to Aleksandr Stroganov, 1o February 1780, quoted in Galante Garrone, Gilbert Romme, 99.

${ }^{52}$ Romme to Dubreul, [summer 1778], Correspondance, 2:431.

${ }^{53}$ Romme to Dubreul, 11 May 1779, Correspondance, 2:530.

${ }^{54}$ Romme to Dubreul, MRM, carton 12, letter 1, 20/10 May (sic) 1780.

${ }^{55}$ Romme to Dubreul, MRM, carton 11, letter 10, 1 October 1779.
} 
Count Stroganov. ${ }^{56}$ These signs of friendship had become all the more important as Romme suffered from homesickness. Letters to his friends included multiple complaints about the food, the climate, and above all, loneliness. These feelings of isolation grew stronger after Golovkin's death. At one particularly gloomy moment, Romme wrote that "the friendship of grandees is of no comfort at all," a statement he would never have made while Golovkin was live. ${ }^{57}$ The lonely Frenchman sought relief by inviting his friend, Jacques Démichel, to join him in Russia, and it was indeed a mark of Stroganov's positive disposition that he agreed to hire Démichel as his personal secretary in order to furnish Romme with a companion. Démichel became tutor to Pavel's second cousin, Grigorii Aleksandrovich Stroganov, in $1784 . .^{8}$

Friendship also found expression in letters Aleksandr Stroganov sent to Romme and Pavel while travelling in the Empress' suite. He addressed them in the same terms in which Romme addressed his Auvergnat friends, as "my dear friends," and "my good friends," expressing the same impatience to hear their news, and a good deal of tenderness. ${ }^{59}$ One letter, written while travelling in the empress' suite, was particularly warm: "my tenderness is known to you, it does not distinguish between you, you are equally dear to me. My son, my friend, he who fills my place, who prepares the future welfare of my child, how can I tell them apart? You, my dear Romme, I throw myself into your arms; [...] and you, my dear son, whom I give my paternal benediction, you, whom I press to my heart, follow the advice of a friend who has made so many sacrifices to be close you, in order to serve as a second father." ${ }^{60}$ Romme did not respond to the count in the same terms of affection, but he prided himself on approaching the count with sincerity and candor, for example, when Aleksandr Stroganov consulted with him on publishing a travel account of Russia: "I should be assiduous in living up to your confidence in me, in telling you frankly what I think, and I should not be afraid to injure your pride (amour propre)." ${ }^{61}$ Such statements were not only manifestations of friendship, but of equality. To Romme, one of the principal duties of a friend was to alert his friends to potential weaknesses, and his willingness to display candor towards Stroganov was perhaps the surest demonstration of friendship he could offer. It cost somethingrunning the risk of incurring displeasure-but it was entirely voluntary.

Romme and Aleksandr Stroganov were consistent in referring to one another as friends and in offering one another tokens of friendship. One cannot overlook, however, that both possessed an ulterior motive: the education of Pavel according to the guidelines set out by Rousseau. For Romme, the motive may have been personal and professional. For Aleksandr Stroganov, it was dynastic. He wanted more than the trappings of a

\footnotetext{
${ }^{56}$ Romme to Dubreul, MRM, carton 12, letter 1, 20/10 May (sic) 1780, letter 2, 4 November 1780; carton 13, letter 2, 19 July 1781 .

57 "L'amitie des grands ne console point." Romme to Dubreul, MRM, carton 14, letter 3, 5 Nov 1782.

${ }^{58}$ Romme to Dubreul, MRM, carton 14, letter 4, 26/6 August 1782; carton 15, letter 1, 27 January 1783.

${ }^{59}$ Aleksandr Stroganov to Romme and Pavel Stroganov, 20 May 1780, 26 May 1780, no date, 1780, 28 July 1785, 4 November 1785, 18 November 1785, 2 December 1785, 29 December [1785], GPAS, 1: 237-243.

${ }^{60}$ Aleksandr Stroganov to Romme, 29 December [1785], GPAS, 1: 243.

${ }^{61}$ Romme to Aleksandr Stroganov, 14 Dec 1785, GPAS, 1: 264.
} 
European education for this child: he wanted a virtuous son, a man, one who would please at court and one who could command, advancing the family's fortunes. ${ }^{62}$ To this end, he was prepared to go to significant lengths. He may not have internalized all of Rousseau's views, but he was prepared to treat his son's governor as a friend, as Golovkin had told him he must.

\section{Virtue}

Treatises on friendship and on education agreed that the key to a child's successful upbringing was the ethical quality of the persons who raised him. Education was understood to be primarily moral, and even for the governor, the object was less to "instruct" a child in "letters and sciences," than to "shape his heart with respect to the moral virtues." Children's dispositions needed to be cultivated correctly: to honor and respect their parents, to be ready to serve their country, to love God and observe the rituals of their faith, to behave with kindness to their neighbors. Vicious parents and governors could accomplish none of this, rearing children into vicious adults. ${ }^{63}$

Friendship as elaborated by sentimental theorists was well suited to play an educational role. Friends were to be maximally open and candid with one another; sharing their joys and sorrows, their thoughts and hopes, and they were to respond candidly to one another's confessions, offering advice and pointing out faults and mistakes. These were not merely duties, but forms of generosity from which a friend stood to benefit greatly. ${ }^{64}$ As Romme proclaimed to d'Harville: "Friendship! It alone can make one believe in virtue; it [alone] can give me courage and strength in a position of misery." ${ }^{65}$ The theoretical literature also emphasized a subtler interaction of sentiments and dispositions, however. Interacting with a friend influenced one's character and could have a balancing effect. A melancholic, for example, could benefit from the friendship of a person of a vigorous and energetic temper, and vice versa. ${ }^{66}$ Last, but not least, friendship

\footnotetext{
${ }^{62}$ See, for example, the count's enthusiastic description of the young Count Andrei Manteufel, who returned from a tour of Europe in 1787. Aleksandr Stroganov evidently saw in him the image of what he would like his son to become: "He's quite a respectable young man, uniting a solid foundation in education with the best conduct and the greatest modesty; in addition, he is widely liked and respected (généralement aimé et estimé). You see, my dear Popo, what are the fruits of a good education [....]. I could not stop myself, my dear friend, from thinking of you as I watched him, wishing that you should resemble him." Aleksandr Stroganov to Pavel Stroganov, 4 March [1787], GPAS, 1: 246-47.

${ }^{63}$ Lefebvre, "Gouverneur d'un jeune homme," 792; Caraccioli, Le Véritable Mentor; Thiroux d'Arconville, De l'amitié, 49.

${ }^{64}$ Sacy, Traité l'amitié, 83-122. This lengthy section of a chapter on "generosity" describes how friends should take care in offering criticism and advice, demonstrating how important these were to friendship in Sacy's estimation. See also Caraccioli, Les caractères de l'amitié, 45-46.

${ }_{65}^{65}$ Quoted in Galante Garrone, Gilbert Romme, 115.

${ }^{66}$ Sacy, Traité l'amitié, 47; Caraccioli, Caracteres de l'amitié, 11, 97.
} 
elicited virtuous feelings and thereby enhanced favorable dispositions of character, the "moral sentiments" such as sympathy, commiseration, and gratitude. ${ }^{67}$

Rousseau held strong views on the benefits of friendship. Personally, he was often suspicious of the advice his friends offered him. ${ }^{68}$ Yet, he helped elaborate the view that friendship plays a formative role in creating virtue. Unlike many of his contemporaries, he believed that the sentiments associated with sympathy, key to sociability, do not come naturally to people, but must rather be trained in people through the experience of interacting with others. This is why friendship was especially important to him. "Our true teachers are experience and sentiment, and man never senses well what behooves him other than through the relationships in which he finds himself." ${ }^{69}$ Personal attachment and friendship teach us that there are others like us; they make us humane. We learn to regret bad deeds, forgive, and be forgiven. These experiences are the basis of our knowledge of morality. ${ }^{70}$ It followed, then, that a governor must be the pupil's "friend, his comrade," "the companion of his games," allowing the pupil to experience and practice how he should interact with others. ${ }^{71}$

Romme was receptive to these ideas, and the cultivation of virtue received the highest priority in the educational program he and Aleksandr Stroganov developed for Pavel. Paragraph one of the contract they signed stipulated that the formation of Pavel's character would be the principal issue of Romme's care: "to attend to everything that can shape the child's character and mode of thinking." 72 In a further document Romme wrote outlining his priorities, he promised Stroganov a son who would be "worthy of all the tenderness of his parents and the respect of good people" (estimé des honnêtes gens). ${ }^{73}$ Years later, he continued to describe his project in these terms, "to make a virtuous man (homme de bien) and a zealous, well-educated citizen." ${ }^{4}$ The formulation, to "make a man" came from Rousseau's Émile; Romme used it fairly consistently, for example writing to tell Dubreul that he looked forward to the day when he would present his pupil to his friends, when Pavel might prove "worthy (digne) of being presented to you. For I want to make a man of him - that is what he shall be when he leaves my arms" (Car j'en veux faire

\footnotetext{
${ }^{67}$ On the general importance of sympathy for Sentimental conceptions of virtue, see Michael L. Frazer, The Enlightenment of Sympathy: Justice and the Moral Sentiments in the Eighteenth Century and Today (Oxford: OUP, 2010); On friendship as key to the development of moral sentiments in Diderot and Rousseau, see Blandine L. McLaughlin, Diderot et l'amitié. Vol. 100-1. Studies on Voltaire and the Eighteenth Century (Banbury: Voltaire Foundation, 1973), 9-10, 65, 77, 94-7, 112.

${ }^{68}$ Rousseau often responded to such advice as tyrannical and self-serving. See William Acher, Jean-Jacques Rousseau: Écrivain de l'amitié (Paris: Nizet, 1971), 126-30.

${ }^{69}$ Rousseau, Émile, 281.

$7^{70}$ Rousseau, Émile, 329, 338-41. "The first sentiment to which a carefully raised young man is susceptible is not love, but friendship" (338).

${ }^{71}$ Rousseau, Émile, 255, 162.

${ }^{72}$ RGADA, f. 1278 , op. 1, d. 348, l. 3. I am thankful to Katherine Zubovich for transcribing this and other documents in RGADA for me.

${ }^{73}$ Romme to Aleksandr Stroganov, n.d., GPAS, 1: 253.

${ }^{74}$ Romme to Aleksandr Stroganov, [1786], GPAS, 1: 258.
} 
un homme il sortira tel de mes mains). ${ }^{75}$ To those with whom Romme discussed his pedagogical mission and who watched him interacting with Pavel, this priority was obvious: "One sees right away that your project is to form a virtuous soul in a healthy body," to make "an honest man and a gentleman" (de l'homme honnête et de l'honnête homme) of him. ${ }^{76}$

Romme was himself disposed to believe that moral qualities were best elicited through friendship, which he viewed as the key to his own emotional and moral wellbeing. In letters to Dubreul and Démichel, he frequently reflected on his duties and requirements as a friend and posited that personal warmth and moral firmness were integrally connected.

"I need indulgent and virtuous friends, whom I might always esteem and who might endure my solitary ways; whose conduct might always edify me, and who might gently and considerately return me to the right path, if I should have the misfortune to stray from it; who might stop me in my mistakes [...], encourage me, and [...] take a certain ascendancy over me that would be impossible if affection, esteem, and trust did not form its basis." 77

Romme appears genuinely to have welcomed criticism and advice from his friends, frequently invoking their importance in his letters. "The sturdiest friendship is one illuminated by reason and truth. I tell you frankly what I think, and I ask you to continue to try me in the same way. Tell me the hardest things; they will shame me (humilieront), but they will not embitter me if they are true. If they are false, I will bring them to your attention with the same sincerity and the same frankness." ${ }^{78}$

It is testimony to Romme's faith in friendship that in his darkest hours in St. Petersburg, he sought relief in the presence of his friend Jacques Démichel, who became the tutor of Pavel's cousin, Grigorii Stroganov. Likewise, Romme cultivated companions for Pavel, believing that their example and personalities would positively influence and complement the boy's. ${ }^{79}$ As Romme found, Pavel, who responded poorly to overt instructions, was happy to imitate his more obedient cousin. Of a livelier and more curious mind than Grigorii, Pavel spurred his cousin to pay attention to their lessons. ${ }^{80}$

\footnotetext{
${ }_{75}^{75}$ Romme to Dubreul, 11 May 1779, Correspondance, 2: 530

${ }^{76}$ Boirat to Romme, n.d., BNF, 4979, f. 52.

${ }_{77}$ Romme to Dubreul, MRM, carton 20, letter 5, 29 April 1789.

${ }^{78}$ Romme to Dubreul, 2 July 1788, in Correspondance 2: 426-7.

${ }^{79}$ Romme to Ekaterina Stroganova, 11 December 1787, GPAS, 1:288. Comparing Grigorii to Pavel: "The latter consults, listens, and submits; the former is prouder, more independent, does not consult, does not listen except when it pleases him, knows neither the condescendence imposed by respect, nor the trust that good reasoning inspires."

${ }^{80}$ Romme to Ekaterina Stroganova, 11 December 1787, GPAS, 1: 287; Romme to Aleksandr Stroganov, n.d. [May 1789?], GPAS, 1: 273-4. Jacques Démichel, then Grigorii's tutor, strongly endorsed the idea, though he
} 
Romme saw similar potential in Andrei Nikiforovich Voronikhin, a serf-alleged to have been Pavel's half-brother-from the Stroganov household. ${ }^{81}$ "This virtuous young man," as Romme referred to him, was manumitted at Romme's request and became like a third pupil during their stay in Western Europe. By "making a man" of Voronikhin, Romme hoped one day to provide Pavel with a valuable moral support, though the difference in social status appears initially to have created substantial difficulties. ${ }^{82}$ All the same, Démichel and Romme continued to hope that Voronikhin's friendship would exert a favorable influence on Pavel after he was separated from his governor in $1790 .{ }^{83}$

Romme clearly viewed friendship as essential to the formation and maintenance of virtuous dispositions. To this end, he did his best to create friends for Pavel as well as offering his own friendship. Multiple conditions needed to be met for this plan to come to fruition, however, and these posed grave difficulties, since they were not entirely subject to the will of governor and pupil. Most crucially, to make friends, they would need to enjoy one's another's company, that is, their relationship must feel like one of inclination, and they must also approach one another as equals.

\section{Equality between Romme and Pavel Stroganov}

Pavel Stroganov was at once Romme's inferior (in age) and his superior (in social status), and they were of rather different temperaments. Romme was twenty-nine years old and Pavel Stroganov seven when their lives were conjoined. Romme was, in his own estimation, of a melancholic disposition, while Pavel, known in the family as "Popo," was energetic and willful. In letters to Dubreul, Romme tried to emphasize the positive. He described experiencing joy in the company of his pupil and he also expressed a liking for Pavel, whose reflections "often surprised" him as "appropriate and fair (justes), lively, and ingenuous." ${ }^{84}$

counted more on Romme's good influence than Pavel's. Jacques Démichel to Baron Aleksandr N. Stroganov, n.d., BNF NAF 4979, folio 168.

${ }^{81}$ This allegation is made in Tatiana de Metternich, Les Stroganoff: Une histoire de la Russie à travers une chronique familiale (Neuilly: V\&O Editions, 1991), 9on. Metternich cites no sources. Even so, Kuznetsov lends her credence. Kuznetsov, Pust' frantsiia, 262. Andrei Voronikhin later became a famous architect.

${ }^{82}$ Romme to Dubreul, MRM, carton 19, letter 5, n.d.; letter 8, 12 November 1788. Voronikhin appears to have suffered a mental breakdown during the first portion of their trip, as reported by Romme to Boirat. Several aspects of Voronikhin's behavior distressed him, among them the latter's excessive displays of deference and hierarchy. Romme to Boirat, ca. May 1788, BNF, 1. 9o. Romme's high opinion of Voronikhin is reflected in his letter to Boirat and the latter's response, which refers to the young man as "your friend" and "dear Voronikin." Boirat to Romme, 28 May 1788, BNF, 1. 63.

83 [Démichel to Romme], 28 December, 179o BNF, 165verso. "I see only one man who could be truly useful to him, that is Voronikin [sic]. I swore everything on the presence of this brave and honest man and I am also greatly counting on d'Otcher himself."

${ }^{84}$ Romme to Dubreul, MRM carton 15, letter 1, 27 January 1783; Romme to Dubreul, MRM, carton 13, letter 2, 19 July 1781 . Romme was not entirely candid in his letters, since his knowledge of the intimate details of Stroganov family life made discretion essential. Yet, expressions of a favorable opinion about Pavel were not coerced either. 
Jean-Jacques had expressed similar sentiments in Émile. A governor should look forward to seeing his pupil, taking pleasure in his health and vivacity, and the pupil should sense joy at the approach of his governor, "his friend, comrade, and companion." Such feelings would be destroyed if the governor, solemn and austere, would begin to correct and lecture him. ${ }^{85}$ Instead, Émile was to learn from the governor by watching him, learning from the latter's successes and mistakes, just as Émile learns from his own. JeanJacques was to be his equal and his "émule," someone to emulate and measure himself against, and he must therefore place himself on a level with Émile. If Émile draws poorly, so will Jean-Jacques. He may not know any geometry, but Jean-Jacques will arrange things in such a manner that they learn it together, with Émile functioning as teacher. "Make [your pupils] your equals," he cried to the tutors of this world, "so that they may become [your equals]. If they cannot raise themselves to your level, lower yourselves to theirs without shame, without scruple. [... T] ake on his shame so that you may erase it: imitate that good (brave) Roman who, watching his army flee and unable to rally it, decided to flee ahead of his soldiers, shouting they're not fleeing, they're following their captain." 86

Romme appears to have tried, at least, to place himself on a level with Pavel. They were together constantly and held all things in common, sleeping in the same room, dressing in the same kinds of clothing, eating the same foods. ${ }^{87}$ Intimating that Pavel shared his abstemious preferences, Romme told Dubreul, "Popo's tastes are absolutely [the same as] mine." ${ }^{\prime 8}$ Yet, Romme also appears to have adjusted his penchants to suit the boy's. In 1782, while still in St. Petersburg, Romme complained cryptically about the "puerility of the way of life that I have adopted." ${ }^{89}$ When Pavel's lessons began in earnest four years later, Romme attended them all, as if he were Pavel's fellow pupil, to serve as his "model (émule), to stimulate his ardor." Afterwards, they would repeat what they had learned during the lesson in conversation. ${ }^{90}$ Romme even came to share his friendships with Pavel. This was most obviously true with regard to Démichel, whose position as governor to Grigorii Stroganov made him a constant companion. In France, Romme and Pavel would also spend extensive time in the home of Countess d'Harville near Paris and with Dubreul in Riom. Pavel even became privy to Romme's correspondence with Dubreul. ${ }^{1}$

\footnotetext{
${ }^{85}$ Rousseau, Émile, 104, 162, 255-6, 272, 328.

${ }^{86}$ Rousseau, Émile, 175-6, 234-5, 374-5. Note that the term, "émule," was also used by the freemasons of the Nine Sisters lodge, to which Romme and Aleksandr Stroganov had belonged.

${ }^{87}$ Romme used this fact to justify to Pavel's mother why she could not spend time with Pavel apart from Romme: "he plays and works before my eyes." Romme to Ekaterina Stroganova, no date, GPAS, 1: 285.

${ }^{88}$ Romme to Dubreul, MRM, carton 17, letter 1, 2 September 1786.

${ }^{89}$ Romme to Dubreul, MRM, carton 14, letter 3, 5 November 1782.

${ }^{90}$ Julia, "Romme, gouverneur," 68. Julia places the word "émule" in quotation marks but does not name the source.

91 "Popo, who read this letter, was very dissatisfied with the first lines and wanted to tear it up." Romme to Dubreul, MRM, carton 17, letter 6, November 1786. See also carton 17, letter 4, 23 October 1786; carton 19, letter 10, 27 November 1788.
} 
It was easier for Romme to lower himself to Pavel's level as a boy, however, than it was for him to raise himself to Pavel's level as the member of a titled family. A paid servant of the household, the governor was in a position of inferiority, and this was especially true of the French outchitel' in Russia, all too often the object of contempt. ${ }^{22}$ Advice manuals urged parents to instruct every member of the household to approach the governor with the utmost respect. "Since his purpose is to take on the functions of a father, it is right that you should reflect upon him a part of the respect that others accord you." 93 Aleksandr Stroganov once again complied punctiliously. In letters cited above, he established equality between himself and Romme, describing Romme as Pavel's "second father" and addressing Romme and Pavel with undivided affection ("you are equally dear to me"). Whether these gestures convinced Romme, Pavel, or anyone else is a separate question.

For Romme, inequality of station remained a problem, and other members of the Stroganov household were less obliging than the count. This was most notably true of Pavel's mother, Ekaterina Stroganova, whom Romme forbade to spend time alone with her son. ${ }^{94}$ Perhaps for this very reason, she continued-prior to her exile from St. Petersburg in 1781 - to treat Romme with "disdainful indifference," exposing him to "contempt and humiliation," as he angrily wrote to her. Her contempt bothered him all the more since he feared her loose morals might corrupt her son and undermine Pavel's respect for his governor. Romme also complained to Stroganova that he felt humiliated by her guests, who covered him in "disrepute and a sort of disgrace (l'espèce de déshonneur)." ${ }^{95}$ Romme must have been relieved when she left St. Petersburg, yet he continued to feel ill at ease, noting that he avoided contact with almost everyone apart from Pavel and Aleksandr Stroganov. ${ }^{96}$

Romme was no less concerned about the influence of servants and strangers on Pavel's morals. The Stroganov palace on Nevskii Prospect abounded in valets and butlers, and Pavel seemed all too eager to issue them commands. ${ }^{97}$ One servant for whom Romme conceived a special affection was J.-F. Clément, who accompanied the pair on their travels to Western Europe. Romme tried to ensure that Pavel would treat Clément with respect and affection. ${ }^{98}$ Generally, very few servants accompanied them on their journeys-both

\footnotetext{
92 "Introduction. III. L’époque de Catherine II", in Mézin and Rjéoutski, eds., Les Français en Russie au siècle des Lumières, 1: 108-9.

${ }^{93}$ Lefebvre, "Gouverneur d'un jeune homme," 792, 793; Caraccioli, Le Véritable Mentor, 17, 72.

${ }^{94}$ Romme to Ekaterina Stroganova, n. d., GPAS, 1: 285.

95 ibid., 1: 284, 286.

${ }^{96}$ Letters to Dubreul. MRM carton 12, letter 1, 20/10 May 1780; carton 14, letter 3, 5 November 1782. Ambiguously, he also wrote "I am well received by Count Stroganov's kith and kin. All that does not prevent me from persisting in my resolution not to see anyone, never to leave my [rooms]. [....] If you love me, do not ask me for more detailed information." MRM, carton 12, letter 2, 4 November 1780.

${ }^{97}$ Romme to Pavel Stroganov, n.d., GPAS 1: 49-5o. Servants were a prominent topic in advice literature: governors are told to keep children away from them. Caraccioli, Le Véritable Mentor, 25.

${ }_{98}$ Clément was, together with Voronikhin, a constant reference point in Romme's letters as a full participant in the group's daily routines. Romme's respect for Clément was expressed in the elaborate funeral ceremony dedicated to him in Auvergne in October 1790. See Chudinov, Zhil'ber Romm, 301.
}

(cc) EY LUKE UNIVERSITY 
within Russia and in Western Europe-much as Georges and Amélie Golovkin had traveled without suites, incognito. After all, Pavel stood to inherit a vast fortune, and traveling incognito allowed him to avoid exposure to the fawning behavior of strangers, which might spoil him. ${ }^{99}$ To this end, Romme took a key measure in October 1788, when he prevailed upon both Pavel and Grigorii to change their last names. Pavel chose d'Otcher, while Grigorii chose Taman, naming themselves after rivers in the Urals where the Stroganov family owned factories and mines. ${ }^{100}$

While the inequality of social status that separated Romme from Aleksandr Strognanov was almost never a topic of discussion, therefore, it was a topic and a problem between Romme and Pavel. Romme took numerous measures to overcome it, among which renaming Pavel was perhaps the most radical, but least invasive and least important. Working from shared experiences-incessant companionship-and things held in common, Romme created an equality that was relational. They were not the same, yet their experiences and possessions became interchangeable. This regime of unremitting companionship, however, imposed its own burdens on both men: essentially, each was the prisoner of the other. Angry exchanges ensued, of which the historian is the unwilling beneficiary, since they occasioned some of the most candid statements about their feelings for one another.

\section{Friendship and free assent}

The friendship between Romme and Pavel Stroganov was marred by one fundamental flaw - it was essentially involuntary in nature, a problem built into it by the very theories that governed their relationship. Educational treatises stipulated that governor and pupil must be friends. Only in this way could the governor "shape the pupil's heart with respect to moral virtues," imprinting "durable impressions" on the child's heart and mind. ${ }^{101}$ Friendship treatises stipulated that friendship was a "union of wills" (volontés), a "perfect union of the hearts," which was supposed to arise from the conformity of tastes and dispositions between two individuals. Friendship could not be willed into being if tastes and dispositions conflicted; to take shape, friendship required the assent of the individual. ${ }^{102}$ This principle was violated in the union between governor and pupil, since they did not choose one another, but were brought together at the initiative of the parent.

\footnotetext{
99 Romme to Aleksandr Stroganov, 18 June 1784, n.d., GPAS, 1: 261, 255. Compare Romme to Dubreul [summer 1778], Correspondance, 2: 432.

${ }^{100}$ Romme to Dubreul, MRM, carton 19, letter 4, 1 November 1788.

${ }^{101}$ Lefebvre, "Gouverneur d'un jeune homme," 792, 794.

${ }^{102}$ On friendship as union of hearts and wills, see: Saint-Évremond, "Sur l'amitié," 409, 416; Sacy, Traité l'amitié, 4; Thiroux d'Arconville, De l'amitié, 3. On selection, choice, see: Sacy, Traité l'amitié, 29-30; Thiroux d'Arconville, De l'amitié, 176-9.
} 
Authors of treatises on friendship and education rarely acknowledged this problem. They did admit, however, that the development of friendship between governor and pupil might be undermined by the former's disciplinary role. Marie Thiroux d'Arconville, for example, acknowledged that children naturally resented their teachers: "Our inborn taste for independence appears, at first glance, to militate against the friendship that children might have for those who rear them. We naturally rebel against everyone who has the right to command us." ${ }^{103}$ The proposed solution was to avoid appearing as if one issued commands, but to defer as far as possible to the "tastes" and inclinations of the child. ${ }^{104}$

Rousseau took this principle to its furthest extreme in Émile, instructing governors never to impose their will on their pupils, but to strike an attitude of "complaisance" instead. ${ }^{105}$ Appearing always to accede to his pupil's wishes, the governor stimulated activity in Émile in such a manner that it appeared as if the impetus to the action had come from inside the boy. Cause and effect were so seamlessly calibrated as to create the illusion of independence: "We never depend on one another but we are always in harmony, and we are never as well with anyone as when we are together." In cases where they did disagree, Jean-Jacques' only disciplinary measure was to remove signs of affection for Émile, such as refusing to play with or speak to him, stimuli to which the pupil naturally responded by adjusting his behavior. ${ }^{106}$

If Rousseau took the principle of free assent to its furthest extreme, this was because his primary aim was to create a "free" person who related to others as "free." The man Jean-Jacques created would be incapable of servility, to the contrary, he was "made to lead (guider), to govern his equals." Others would follow him automatically, without even realizing it, for "talent and experience" had taken the place of "right and authority." ${ }^{107}$ This kind of leadership, it would appear, would also be the one practiced by Jean-Jacques on Émile.

Rousseau posited a relationship in which both participants felt free and independent. Neither Romme nor Pavel appear to have felt this way. Romme described his life to Dubreul as requiring extreme self-abnegation, a "path of thorns," along which he must "forget my tastes, my projects, my existence, in order to occupy myself entirely with that of another." ${ }^{108}$ It was not just the time involved that drained Romme, but the need always to put on a cheerful countenance. Explaining why he wrote so rarely to friends, Romme noted: "my pupil, who likes me very much (m'aime beaucoup), is far from

\footnotetext{
${ }^{103}$ Thiroux d'Arconville, De l'amitié, 47.

104 "When his tastes are reasonable, even if they are opposed to your own, adapt yourself to them with good grace." Lefebvre, "Gouverneur d'un jeune homme," 794. See also Caraccioli, Le Véritable Mentor, 79; Thiroux d'Arconville, De l'amitié, 49-50.

${ }^{105}$ Rousseau, Émile, 204-5, 276.

${ }^{106}$ Rousseau, Émile, 200-5; harmony quote on 255. Lefebvre, “Gouverneur," 794, too, recommends removal of affection, though it also endorses "severe punishment."

${ }^{107}$ Rousseau, Émile, 258-9.

${ }^{108}$ Romme to Dubreul, MRM, carton 14, letter 2, 6 June 1782; carton 13, letter 3, 28/8 October 1781. Julia concurs that there was a sacrifice involved: "Gilbert Romme gouverneur," 54-5.
}

(cc) EY DU UUKE UNIVERSTYY 
appreciating the need to confide one's troubles in order to relieve them, and I have sensed the danger of letting my grief always be visible to him. I have thus been cheerful by obligation, while mental stupor, by prudence, set in at the appropriate hours." ${ }^{109}$ Further, Romme was weighed down by anxiety over the delicate task of organizing his pupil's experiences for him. "Even while doing all the good one can foresee, one's conscience is never at rest, for one senses that one cannot foresee everything, and that a minor error with no consequence in the present may become the most lethal seed the future can develop, despite all the care taken by the most active and most honest supervisor." 110 Given his adherence to Rousseau's theory, Romme's anxiety was appropriate, since every misstep on the pupil's part could be attributed to the governor's failure to organize his energies and experiences appropriately.

When conflicts did arise between governor and pupil, Romme responded with almost visceral pain. He tried to imitate Jean-Jacques, at times withdrawing affection and turning a cold shoulder, at times steering Pavel subtly, as "one friend guides another" (comme un ami dirige un autre). ${ }^{111}$ With increasing frequency, however, Romme resorted to angry reproach, as can be seen in the letters he and Pavel wrote to Aleksandr Stroganov, as well as notes they left one another. Romme's complaints began before Pavel reached puberty, but they became frequent in 1786, when Pavel was 14 years old, continuing at varying levels of intensity until the pair's separation in 1790. The boy's physical maturation and growing strength, Romme complained, seemed to deprive him of mental and moral energy. Adolescence produced mental torpor and "great physical sensitivity" at once in Pavel, leading to "laziness, insouciance," and loss of concentration. ${ }^{112}$ Romme varied his account, but his accusations centered on a tight cluster of vices: lethargy, apathy, boredom, laziness, feebleness, obliviousness [étourdie], and lack of sensitivity. ${ }^{113}$ Pavel's rebellion took the form of displays of indifference-real or feigned.

Romme had difficulty feigning indifference. His withdrawals of affection could be quite explicit, and his statements of disappointment express a very real sense of attachment, such as when he passionately declared that he was no longer Pavel's friend: "I am no longer your friend, sir; live alone and expect neither conversation, nor games, nor pleasures from me. And if your obliviousness still allows you a few instants of reason, then weep over your faults, and do not appear before me. I need to be away from you in

\footnotetext{
${ }^{109}$ Romme to Dubreul, MRM, carton 14, letter 3, 5 November 1782.

${ }^{110}$ Romme to Dubreul, MRM, carton 14, letter 2, 6-8 June 1782.

${ }^{111}$ Romme to Aleksandr Stroganov, n.d., GPAS, 1: 259

${ }^{112}$ Romme to Aleksandr Stroganov, n.d., GPAS, 1: 255. See also Romme to Aleksandr Stroganov, Geneva 27/16 November 1787, RGADA, f. 1278, op. 1, d. 348, 1. 109. Romme to Boirat [1786], BNF 4979, folio 73 verso.

${ }^{113}$ These complaints sometimes came in postscripts to letters. Chudinov notes one such postscript of 2/13 June 1780 , to a letter dated 27 May 1780, in which Romme complains to Aleksandr Stroganov of Pavel's "distractedness, insouciance, inertia, and laziness'." Chudinov, Zhil'ber Romm, 159. The original is in RGADA, f. 1278, op. 1, d. 348, l. 206 ob.
} 
order to dispel the pain that I have at not having found in you the friend I seek and on whom I made the entire happiness of my life dependent."114 These thoughts and feelings were fully communicated by Romme to Aleksandr Stroganov, whom he kept apprised of their difficulties, complaining that his efforts seemed to make no impact at all on this seemingly "insentient" youth: "I hoped that good advice, honesty, and the good example of those around him would alter his bad penchants towards laziness, coarseness, obstinacy, and indifference toward everything, but I was mistaken. Your son feels nothing. Venez-vous avec nous, bon père, you have a son who is insensible to friendship. I withdrew my care from him, I abandoned him, but nothing affects him. He plays with a dog to console himself over the loss of a friend." 15 (The point about the dog seemed particularly to irk Romme, who mentioned it twice in notes to Pavel. ${ }^{116}$ )

Breaking with the script of Émile, Romme even tried telling his pupil what to dowith adverse results-as well as appealing to his pupil's reason. ${ }^{117}$ The exasperated governor also tried threats, as when he warned Pavel that his obnoxious behavior would make a pariah of him: "Eh, you wretch, if you continue like this you will become the most contemptible, the most disgusting being." ${ }^{118}$ Last, but not least, Romme resorted to the base principle of authority, finding he needed to draw on the authority of the father. For example, in letters from around 1787, he would ask Aleksandr Stroganov to direct a few words to his son, including "some thoughts on the necessity of remaining attached to me, as he is to you. Confirm the rights that I have over him. [...] It is time to fortify his trust in me." 119 The count did his best to oblige, answering in a letter to Romme and Pavel: "follow the instructions (avis) of a friend who has made so many sacrifices to be by your side, to be a second father to you." ${ }^{120}$ When Romme despaired even of these measures, he threatened to quit, asked to be relieved of his duties, and complained that in addition to

\footnotetext{
${ }^{114}$ Romme to Pavel Stroganov, n.d., GPAS, 1: 52.

${ }^{115}$ Romme to Aleksandr Stroganov, 1786, GPAS, 1:268. See also Romme to Aleksandr Stroganov, n.d., GPAS, 1: 256.

${ }^{116}$ See Romme to Pavel Stroganov, n.d., GPAS, 1: 49 and 5o.

${ }^{117}$ Reasoning with one's pupil is senseless, according to Rousseau, because reason as a mental faculty develops only through experience. Children need experience to learn why they should or should not behave in certain ways. Rousseau, Émile, 155-56, 164. By contrast, Romme wrote to Aleksandr Stroganov on 27/16 November 1787: "Reason, which is the only weapon I would like to use against him, is not always sufficient." RGADA, f. 1278, op. 1, d. 348, l. 109. Another respect in which Romme broke with the precepts of Émile was by accusing Pavel of ingratitude, something Rousseau said a tutor must never do. Rousseau, Émile, 357.

${ }^{118}$ Romme to Pavel Stroganov, GPAS, 1: 51. See Romme to Aleksandr Stroganov, 1786, GPAS, 1: 268: "I pity him, he will be wretched, held in contempt by everyone, if he continues, he will not have a single friend who will console him in misfortune or nurse him when he is ill."

${ }^{119}$ Romme to Aleksandr Stroganov, 27/16 November 1787, RGADA, f. 1278, op. 1, d. 348, 1. 109.

${ }^{120}$ Aleksandr Stroganov to Romme and Pavel Stroganov, 29 December [1785], GPAS, 1: 243; 11 November 1787, GPAS, 1: 245. See also Aleksandr Stroganov to Romme and Pavel Stroganov, 4 March 1787: "I cannot refrain from writing to you, in order to recommend to you, in the name of my paternal tenderness and of everything most sacred, to conduct yourself wisely, to apply yourself and to content yourself with my best friend and your own. Monsieur Romme is the one who replaces me at your side, and you must love and respect him as a second father." GPAS, 1: 247.
}

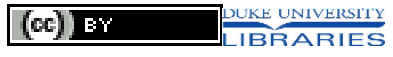


everything else, he missed home. ${ }^{121}$ Romme even fled the Stroganovs' mansion for the French embassy on one occasion and had to be persuaded to return by the ambassador. ${ }^{122}$

Amidst all his complaints, however, Romme was prepared to admit that Pavel had some good traits: he was physically fit, "charitable, humane, just," with a "good heart, sensitive, and very innocent." Pavel's judgment was sound; he had a lively understanding and "a rather strong temperament." ${ }^{23}$ Nor do the boy's letters to his father and notes to Romme strike one as the writings of an insentient creature. He apologized for his "laziness," admitting that "Mr. Romme" (gospodin Rom) had tried his best to eradicate this failing, but that he, Pavel, had been "too stupid" to listen to him. ${ }^{124}$ Pavel was also capable of expressing gratitude to Romme, as reflected in a letter of 1790. "I am very grateful for the keen solicitude that you have unceasingly shown me." He was, he said, aware that Romme constantly worried "whether or not I am indifferent as to my own conduct," and tried to reassure him. "I have always paid the greatest attention to everything you were able to tell me on this topic; I have done so every time, and I still sense its full importance." ${ }^{125}$ The occasion for this apology had been Pavel's confession, at the age of eighteen, to being unable to refrain from masturbating. Romme had been touched by Pavel's openness and candor ("You showed me a moment of trust by confessions that it was urgent to deposit in a heart that is devoted to you"), though Romme remained terribly worried by the "inevitable consequences" of this "sinister" problem (the consequences went unnamed). ${ }^{126}$

Openness and candor could only be voluntary, and these were the qualities that Romme attempted to elicit in his pupil as best he could. Like Rousseau's Jean-Jacques, he wanted to make "a man" of his pupil, one who could form judgments, opinions, and decisions independently. To accomplish this, Romme tried to mask the essential power differentials and reciprocal dependence in their relationship. Yet, from the very outset, the principles of authority, compulsion, dependence, and obligation were clearly written into their roles, and Romme fell back on making them explicit from time to time. These lapses were significant, for authority and obligation were precisely the elements that he and his contemporaries were attempting to banish from their social interactions-so much so that they believed the relationship between governor and pupil must be cast as a friendship in order to succeed.

\footnotetext{
${ }^{121}$ Romme to Aleksandr Stroganov, n.d., GPAS, 1: 258-9; Romme to Aleksandr Stroganov, March 1786, GPAS, 1: 267; Romme to Aleksandr Stroganov, 1786, GPAS, 1: 269.

${ }^{122}$ Chudinov, Zhil'ber Romm, 166.

${ }^{123}$ Romme to Aleksandr Stroganov, n.d., GPAS, 1: 256.

${ }^{124}$ Postscript by Pavel Stroganov in a letter from Romme to Aleksandr Stroganov, 8 March 1788, RGADA, f. 1278, op. 1, d. 348, 108 ob.

${ }^{125}$ Pavel Stroganov to Romme. Paris, 6 May 1790, GPAS, 1: 300-1.

${ }^{126}$ Romme to Pavel Stroganov, 5 May 1790, GPAS, 1:310. On eighteenth-century conceptions of masturbation and Rousseau's Émile, see Thomas W. Laqueur, Solitary Sex: A Cultural History of Masturbation (New York : Zone Books, 2003), 42-43.
} 


\section{Independence}

Pavel was never given a choice, whether Romme should be his governor and friend. For this reason, it remained unclear to all involved-including, it seems, Pavel himself-how he felt about Romme and whether the imprint Romme left on him was permanent. Had the governor succeeded in "shaping his [pupil's] heart and mind with respect to moral virtues"? It is noteworthy how much anxiety this question caused when the prospect of separation between pupil and governor was raised. His friend, Jacques Démichel sympathized fully and mediated between Romme, Aleksandr Stroganov, and Nikolai Nikolaevich Novosil'stev, the count's nephew who came to collect Pavel.

Romme and Démichel's fears were based in part on prior experience. In March 1789, when Grigorii's father had died, Pavel's father became his guardian and called Grigorii home to St. Petersburg, together with his tutor, Démichel. The task was to establish Grigorii quickly in service and as inheritor to his father's estate, to groom him for these functions, and to alert him to the various political factions that would make demands upon him. ${ }^{127}$ This rapid change in status quickly went to Grigorii's head. Romme summarized Démichel's report of July 1789 in a letter to Dubreul: "the return of his pupil into his family has produced a rapid und unfavorable change in [Grigorii's] character. $\mathrm{M}$ [onsieur] $\mathrm{D}$ [émichel] is no longer heeded, nor even consulted. His guardians [tuteurs] begin to realize that they have miscalculated and seem determined to send him back to France." ${ }^{128}$ Aged eighteen, Grigorii had proven immature, a man neither in the eyes of his French tutor, Démichel, nor in the eyes of his Russian guardian, Aleksandr Stroganov. The experience boded poorly for Pavel Stroganov, whom Romme had long identified as the more intelligent but more unruly of the two.

More poignantly, Romme feared that twelve years of labor with Pavel would be wasted if he were not allowed to conclude the last, vital part of the boy's education. Émile had stipulated that when he turned twenty, the young man should be introduced gradually into the world of high society in order to learn the "art of living among his fellow men" (avec ses semblables). This was an art the governor could not teach, for the "grand monde" of high society operated according to its own laws. It was corrupt and corrupting; the former pupil must enter it with the greatest caution, relying on the counsel of friends, especially his best friend, his former governor. This alone would allow him to maintain his dignity and independence among people who sought to take them from him. ${ }^{129}$ In addition, the governor must supervise the young man's relationships with women and help him find a suitable spouse, "Sophie," as she is called in Émile. The titular

\footnotetext{
${ }^{127}$ Romme to Dubreul, MRM, carton 20, letter 16, [1789]. Grigorii's father was Baron Aleksandr Nikolaevich Stroganov.

${ }^{128}$ Romme to Dubreul, MRM, carton 20, letter 20, 24 August 1789.

${ }^{129}$ Rousseau, Émile, 475, 490-1, 496.
} 
hero is roughly twenty-two years old when he marries, and it is with the consummation of their marriage and Sophie's pregnancy that the book ends. ${ }^{130}$

Any apprehensions Rousseau sowed in Romme's mind as to the young man's passage into social life were compounded by his low opinion of the future that lay in store for Pavel. As he wrote to Countess d'Harville, Romme had sacrificed "the best years of my life, the interaction with my friends, my tastes," even his filial duties for the sake of educating Pavel to become a "free man." Now, Pavel was to be removed from his care, just as the project entered its critical phase. Why should all his efforts come to nothing more than the formation of a "slave, a man of court, a flatterer?" ${ }^{31}$ Differences, perhaps long hidden, perhaps heretofore unclear to the participants themselves, were now openly expressed.

The slavery Romme had in mind, following Rousseau, was the dependence of the well-born individual on the recognition of others. In courtly society, one's sense of selfworth is determined by the ability to acquire attributes that are extrinsic to one's person as an individual. Rousseau called this unhealthy and unnatural sense of self "amour propre" and contrasted it to "amour de soi," the natural impulse to protect and look after oneself. As Rousseau wrote, "Amour de soi, which attends only to ourselves, is content when our true needs are met; but amour propre, occupied with comparisons, is never content and does not know how to be, because that sentiment which prefers us to others, also demands that others should prefer us to themselves, which is impossible." ${ }^{\prime 32}$ In other words, amour propre, which impels individuals to dominate others, in fact places them in a condition of dependence on the opinion of others.

To Romme and Démichel, the embodiment of amour propre was Nikolai Novosil'tsev, whom they regarded as a kind of anti-Pavel. Aged twenty-nine, the illegitimate son of Aleksandr Stroganov's brother had been raised in Russia without a proper education. He represented what Pavel might have become had the latter not been raised by Romme. Novosil'stsev was not obnoxious in his manners; but he was deemed servile. "Accustomed from childhood on to bend his will beneath that of others, [Novosil'tsev] has contracted the habit of a complacency which deprives him of the energy he ought to have. He is imbued with the disastrous conviction that, under the government in which he lives, one must blindly submit one's opinion, one's tastes, one's particular views to the will of those on whom one depends."133 Démichel also remarked

\footnotetext{
${ }^{130}$ Rousseau, Émile, 624, 635-6, 703. In practice, Romme does not appear to have kept close watch of Pavel's relations with women. Pavel married within a few years of his separation from Romme. Appropriately, the woman's name was Sophie-- Sofi'a Vladimirovna Golitsyna.

${ }^{131}$ Romme to Mme d'Harville, [15 July 1790], quoted in Galante Garrone, 238.

${ }^{132}$ Rousseau, Émile, 329. See also Gerald M. Mara, "Rousseau's Two Models of Political Obligation," Western Political Quarterly 33, 4 (1980), 536-49: 539.

${ }^{133}$ Démichel to Romme, 28 December 1790, BNF, folio 165 verso.
} 
that most of Novosil'tsev's decisions appeared to be made in fear of displeasing his uncle. $^{134}$

Almost immediately, Novosil'tsev began dressing Pavel in fancy clothes, showing him how people behave in "good company," and introducing Pavel into high society, permitting him "entertainments" that had previously been forbidden. ${ }^{135}$ Partly, Démichel supposed, Novosil'tsev was trying to curry favor with Pavel, but more importantly, he wished to satisfy Aleksandr Stroganov. "Mr. Nov. appears to have one sole object in sight, and that is to please the count." Démichel declared their mission to be entirely irreconcilable with the one he and Romme shared: "our manner of seeing things will never be that of the count, nor probably that of Mr. Nov., whose orders are contrary to what you wish for." Novosil'tsev was attempting nothing less than to undo their entire project, so that he could "return [Pavel] to his father in a state entirely different from the one he was in when he left your hands (sortant de vos mains)." ${ }^{136}$ Yet, Démichel hoped that Pavel would not be tricked by Novosil'tsev's ruses. "This kind of character cannot long command Otcher's respect and will destroy any trust that his compliments may have given rise to."137 Démichel was obviously relieved to report that Novosil'tsev's efforts to ingratiate himself with Pavel met limited success, an observation he repeated several times. "Mr. Nov. may have excellent qualities in your eyes, in mine, and in [the eyes] of society in general, but he does not have the ones that suit Otcher." ${ }^{138}$ Pavel was of course polite, but "I have yet to see the slightest inclination to bestow trust in Mr. Novosilischoff (sic), and I am pleased to see this reserve." 139 Pavel's cooperative demeanor allowed Novosil'tsev to suppose that the boy was easily manipulated, but Novosil'tsev's failure to closely observe Pavel meant he was deluded..$^{140}$

Asserting that Novosil'tsev was deluded, Démichel also intimated that Pavel did indeed possess a firm character, one best known to himself and Romme. Watching Pavel interact with others at high society events to which Novosil'tsev invited him with Pavel, Démichel's initial reports were positive: "Otcher" behaved with discretion and reserve ("il

\footnotetext{
${ }^{134}$ Démichel to Romme, 14, December 1790, BNF, folio 162.

${ }^{135}$ Démichel to Romme, 28 December 1790, BNF, folio 165. As Démichel put it, these gestures were intended "to make Pavel lose some of the coarseness that one attributes to him in high society and to make him adopt a different style of dress and manners more analogous to the tone which one calls "good company."

${ }^{136}$ Ibid.. Rousseau had warned that a young man could be transformed to the point of being unrecognizable within 6 months if his introduction into high society was not orchestrated carefully. Émile, 494.

${ }^{137}$ Démichel to Romme, 28 December 1790, BNF, folio 165 verso.

${ }^{138}$ Démichel to Romme, 28 December 1790, BNF, folio 165 verso.

${ }^{139}$ Démichel to Romme, 12 December 1790, BNF, folio 159.

140 "Otcher's frank and gay manner, the facility with which he adjusts to everything that is proposed to him, make him [Novosil'tsev] think that Otcher has already forgotten you, and that it will be easy to make him do everything that will be required of him in Russia; you know how much he is mistaken." Démichel to Romme, 14 December 1790, folio 162. See also 28 December 1790, folio 165: "He has not given himself the trouble to observe Otcher, and he has not seen how easy it is for a bird to escape the cage in which one has trapped it."
} 
sait se taire apropos"). ${ }^{141}$ But he was equally capable of expressing his views, delivering them with impressive candor and precision. As Démichel reported, he was not the only one watching Pavel closely: "His physiognomy, his thoughtful, decided, and spirited manner generally strike those who see him and inspire the greatest interest in him." ${ }^{142}$ "I am counting greatly on this brave youth to be able to speak the truth at all times he should deem it necessary." 143

Pavel gave Romme and Démichel ample grounds for hope. Upon learning that he was to be separated from Romme, he wrote a letter of remonstrance to his father: it was "not without grief," he wrote, that he had read of his forthcoming separation from Romme after 12 years together. ${ }^{144}$ Pavel also wrote an angry letter to Démichel, faulting his father for siding against Romme. "I cannot lie to myself," he wrote, "my father is extremely weak." He further pledged his loyalty to Romme and to the republican political principles the two had recently become immersed in. "Undoubtedly, one hopes that one will make me change my opinion, as a weathervane turns when the wind changes, but this weather vane is fixed on its pivot." Returning to Russia would be difficult for him; "a crowd of enemies" awaited them there and would try to prevent him from serving his "fellow citizens." They would not, however, stand in the way of his career, since he had no intention of pursuing one. "I am not disposed to risk my life for the caprices of an ambitious woman," he wrote, referring, presumably, to Catherine II. ${ }^{145}$ Similarly comforting words were forthcoming for Romme. In his second to last letter to Romme, Pavel vowed that he would never become a hypocrite, but would always speak his mind, even if it meant becoming "a victim of despotism." 146

Romme's last letter, written from Paris on 9 December to Pavel in Strasbourg, was exceedingly long and reads like a testament. Once more, Romme conveyed the precarious status of his project for Pavel: "I had the ambition of making a man of you, and now one wants you to be afraid lest you show yourself to be one! Oh, my friend!" Summarizing what he regarded as the attributes of manhood, Romme listed actions rather than words: the "courage of great virtues," speaking little but acting well, commanding one's passions, and cultivating friendship. "If that is man, then do not simply blush at wanting to be such, but may all of your efforts contribute toward becoming one." ${ }^{147}$ Romme encouraged Pavel to write, and to be candid about his feelings. Pavel's response, sent from Strasbourg on 14 December, lacked the bluster of his missives one month earlier. He confessed to

\footnotetext{
${ }^{141}$ Démichel to Romme, 12 December 1790, 14 December 179o BNF, folios 159, 161. The fine art of knowing when to remain silent was a highly prized skill in the eighteenth century.

${ }_{142}^{14}$ Démichel to Romme, 14 December 1790, BNF, folio 161.

${ }^{143}$ Démichel to Romme, 12 December 1790, BNF, folio 159.

${ }^{144}$ Pavel Stroganov to Aleksandr Stroganov, 12/1 December 1790, GPAS, 1: 362.

${ }_{145}$ Pavel Stroganov to Démichel, November 1790, GPAS, 1: 302-4.

${ }^{146}$ He continued, presciently: "These are beautiful words, you tell me, it is not sufficient to write them, they need to be executed; I promise you to do my utmost." Pavel Stroganov to Romme, 11 December 1790, GPAS, 1: 306 .

${ }^{147}$ Romme to Pavel Stroganov, 9 December 1790, GPAS, 1: 312.
} 
being afraid. "Oh, my friend, how difficult is my task! To be placed in charge of one's own education at the age of 18 , to be the sole preserver of one's innocence in the midst of the most unbridled corruption - I confess to you that this idea frightens me." ${ }^{148}$

Aware that he would not see or enter into direct correspondence with Romme again, Pavel was inclined to look back and sum up.

"It is when one is separated from one's friends that one feels their value; you know that I did not always submit full-heartedly to the privations that you were in a position to demand of me, and I remember that this sometimes put me in a very bad mood. But now that I consider how small these petty, temporary disagreements are in comparison to those I most likely face before me, I must confess to you that when I reflect on this, it evokes in me the most agreeable memories, but [ones] that are followed by bitter regrets." ${ }^{149}$

This leave-taking could not have been more different from the letter Georges Golovkin had sent to Romme just over ten years earlier. Where Gololovkin had offered consolation and assurances, Pavel Stroganov expressed doubts, reprimands, and remorse. Still, Pavel was able to list some positive memories, comprehensive of their experiences together their travels, time spent with his father, their studies together, their experiences in revolutionary Paris. ${ }^{150}$

In another ten years, Pavel Stroganov would remember his life with Romme rather differently. A brief autobiographical work he wrote in 1803 , describes Romme as an "Enthusiast" who passed on his "exalted" political views to his pupil. Their experiences of the French Revolution are described, in this account, as a dizzying string of bizarre events. Travelling back to Russia, he says, his growing intimacy with Novosil'tsev helped set his head straight. Nevertheless, upon his return to Russia, Stroganov says, he was regarded in high society as "gangrened"; a "strange animal." ${ }^{\text {"51 }}$ The young count's wish to distance himself from Romme and from his experiences in revolutionary France may well have been motivated by the rise of anti-French sentiment in Russia before the Treaty of Tilsit, as well as by his newly acquired power under Alexander I as a member of the "Unofficial Committee," in which he played a leading role. ${ }^{152}$

Still, Pavel Stroganov's account of a rapid change of heart in his memoir is corroborated by the fact that Pavel did not write to his French friends upon his return to St. Petersburg. He appears to have sent one letter to Démichel in 1792, who begged Pavel

\footnotetext{
${ }^{148}$ Pavel Stroganov to Romme, 14 December 179o, GPAS, 1: 307.

${ }^{149}$ Pavel Stroganov to Romme, 14 December 1790, GPAS, 1: 306-7.

${ }^{150}$ Ibid.

${ }^{151}$ P.A. Stroganov, "Histoire de mon temps," ed. Mikhail Safonov, in Les Archives de l'Est et la France des Lumières, 2: 700-3. Pavel Stroganov's account of Romme as an exalted-and therefore misguided-tutor is repeated in the memoirs of Pavel's later friend, Prince Adam Czartoryski, Memoirs and his Correspondence with Alexander I, ed. Adam Gielgud 2 vols. (London: Remington, 1888), 163-4.

${ }^{152}$ Safonov, "L'Histoire de mon temps de Pavel Aleksandrovitch Stroganov," 696-97.
} 
to write to Romme in the name of their old friendship, but to no avail. ${ }^{153}$ A similar, milder letter of reproof reached Pavel years later from Romme's Parisian friend, d'Harville, whom Pavel and Romme had visited several times in 1789 and 1790 . She wondered why she had not heard from Pavel since his departure and carefully inquired whether he had heard anything from Romme. ${ }^{154}$ At this point, Romme was dead, having committed suicide in prison in 1795 as a member of the Montagnards. ${ }^{155}$

\section{Conclusions: Friends, Clients, and Patrons}

"Modern observers may find it difficult sometimes to distinguish between friends and clients," Sharon Kettering observed in her often-quoted article, "Friendship and Clientage in Early Modern France." As she explains, there was not even a word for patronage and clientage in early modern Europe, with "friend" and "friendship" serving as a universal and rather pliable descriptor for a range of "mutual assistance relationships." Kettering did her best to distinguish: "Friendship was a free, horizontal alliance providing mutual assistance without a quid pro quo [....]. Clientage, on the other hand, was an unequal, vertical alliance between a superior and inferior based on reciprocal exchange. The reciprocity of the exchange was obligatory." ${ }^{156}$

Following Kettering's method and definitions, the ties that bound Romme, Aleksandr Stroganov, and Pavel Stroganov would not qualify as friendship, despite their protestations of attachment and loyalty. Were they confused? The problem is acute, especially given that, unlike Kettering's subjects, these three had a well-developed vocabulary to distinguish between friends and patrons, one that was well elaborated in published tracts by the middle of the eighteenth century. They had only to look at the relevant passage in Émile to see the difference: independence, equality, and candor were arrayed against patronage, courtliness, and obligation. Familiar as they were with this distinction, Gilbert Romme and Aleksandr Stroganov insisted consistently that they were friends between 1779 and 1790, while Pavel Stroganov, whom no one ever asked, played along.

The question structuring Kettering's article-“friend or client?"-is in fact illposed. One problem is that the constituent elements used to characterize the difference, such as equality and servitude, had themselves changed in meaning over time, acquiring

\footnotetext{
${ }^{153}$ Démichel to Pavel Stroganov 14 March 1792, GPAS, 1: 319-30.

${ }^{154}$ D'Harville to Pavel Stroganov, 1796, GPAS, 1: 321. Chudinov asserts that she was writing in 1798 in response to rumors that Romme had fled the revolution to live with Pavel Stroganov in Russia. Chudinov, Zhil'ber Romm, 317.

${ }^{155}$ Romme had been condemned to death by guillotine together with 5 other Montagnards for supporting a protest by sans-culottes. He committed suicide by stabbing himself repeatedly in the stomach with a small knife on the eve of his planned execution. His late career is described in greatest detail in Galante Garrone, Gilbert Romme.

${ }^{156}$ Kettering, "Friendship and Clientage in Early Modern France," 144-6.
} 
special importance in the middle of the eighteenth century as education conferred new social prestige. Another problem is that the answer itself preoccupied the persons investigated. Romme, Aleksandr Stroganov-perhaps also Pavel Stroganov-wished to think of themselves and be thought of as friends. Even Nikolai Novosil'tsev, ever attuned to expectations of others, got this right in reporting on what he had seen when he encountered them in 1790. Pavel and Romme were remembered as "two friends who understood each other so well." 157

Gilbert Romme and Aleksandr Stroganov constructed their relationship as a friendship for a variety of reasons. Most critically, they deemed this essential for Pavel's successful education, to make him a virtuous man, capable of leadership, not a "man for sale." What is more, their attitudes to education, influenced by Rousseau's Émile and other writings of the mid-eighteenth century, shaped their conceptions of self. Of the three, Gilbert Romme had studied Rousseau's theories in greatest depth. It seems unlikely that he would have agreed to become Pavel Stroganov's governor under any other conditions than as a "friend" of the family (as opposed to a hired servant). Aleksandr Stroganov, less reflective than Romme, nevertheless liked to think of himself as an enlightened person, a powerful courtier, but one no less capable of putting others at ease. In befriending the Frenchman, he could continue to live out an activity he had cultivated in his years in Paris, when he regularly invited "celebrated authors" to his home. Pavel Stroganov's situation was unenviable. He may not even have read Rousseau until the time he and Romme separated, and of the three, his feelings and behavior were clearly the most ambivalent. His guardians' ambitions hinged on his willingness to submit voluntarily to their plans for friendship and to perform the roles they had invented for him.

${ }^{157}$ As reported by Czartoryski, Memoirs, 164 . 